\title{
Viability of Mimosa caesalpiniifolia Benth. seeds as a function of fruit maturity stage and storage temperature
}

\section{Viabilidade de sementes de Mimosa caesalpiniifolia Benth. em função do estádio de maturação do fruto e temperatura de armazenamento}

\author{
Karine Pacheco de JESUS ${ }^{1}$; Edvânia da Silva CARVALHO²; Manuela Oliveira de SOUZA ${ }^{3}$; Josival Santos \\ SOUZA $^{4}$; Andrea Vita Reis MENDONÇA ${ }^{5}$ \\ ${ }^{1}$ Engenheira Florestal, Mestranda pelo Programa de Pós-graduação em Recursos Genéticos Vegetais da Universidade Federal \\ do Recôncavo da Bahia (UFRB), Rua Rui Barbosa, Cruz das Almas - BA, CEP. 44380-000, karinepacheco28@gmail.com \\ ${ }^{2}$ Autor para correspondência, Bióloga, Mestre em Recursos Genéticos Vegetais, Universidade Federal do Recôncavo da Bahia \\ (UFRB), edvaniacarvalho19@hotmail.com \\ ${ }^{3}$ Bióloga, Doutora em Biotecnologia, Centro de Ciências Exatas e Tecnológicas (CETEC), Universidade Federal do Recôncavo \\ da Bahia, manuelasouza@ufrb.edu.br \\ ${ }^{4}$ Engenheiro Florestal, Doutor em Biociências e Biotecnologia, Centro de Ciências Agrárias Ambientas e Biológicas (CCAAB), \\ Universidade Federal do Recôncavo da Bahia, josival.ufrb@gmail.com \\ ${ }^{5}$ Engenheira Florestal, Doutora em Produção Vegetal, Centro de Ciências Agrárias Ambientas e Biológicas (CCAAB), \\ Universidade Federal do Recôncavo da Bahia, andrea@ufrb.edu.br
}

Recebido em: 21-03-2021; Aceito em: 30-06-2021

\begin{abstract}
The maintenance of seed viability during storage is influenced by several factors related to the species and to the environment. This work aimed to determine the viability of Mimosa caesalpiniifolia seeds from unripe and ripe fruits stored at different temperatures (ambient, $10 \stackrel{\circ}{\circ}, 0 \stackrel{\circ}{-C}$ and $-21^{\circ} \mathrm{C}$ ). For this, the germination performance of the seeds was evaluated at $0,3,6$ and 12 months of storage. The experimental design was completely randomized, with four replicates of 25 seeds per treatment. The variables evaluated were: number of germinated seeds, number of hard seeds, number of unviable seeds and number of normal seedlings. The storage potential of $M$. caesalpiniifolia seeds depends on the fruit maturity stage. Seeds from unripe fruits without drying do not tolerate storage. Seeds from unripe fruits with drying at $15 \%$ water content maintain viability, for 12 months, when stored at a temperature of $10{ }^{\circ} \mathrm{C}$. Seeds from ripe fruits without drying maintain viability, for 12 months, when stored at temperatures of $0^{\circ} \mathrm{C}$ and $10^{\circ} \mathrm{C}$.
\end{abstract}

Additional keywords: Fabaceae; germination; seed storage.

\section{Resumo}

A manutenção da viabilidade da semente durante o armazenamento é influenciada por diversos fatores relacionados à espécie e ao ambiente. Este trabalho teve por objetivo determinar a viabilidade de sementes de Mimosa caesalpiniifolia provenientes de frutos verdes e maduros armazenadas em diferentes temperaturas (ambiente, $10^{\circ} \mathrm{C}, 0^{\circ} \mathrm{C}$ e $-21^{\circ} \mathrm{C}$ ). Para isso, o desempenho germinativo das sementes foi avaliado nos períodos de 0, 3, 6 e 12 meses de armazenamento. O delineamento experimental foi o inteiramente casualizado, com quatro repetições de 25 sementes por tratamento. As variáveis avaliadas foram: número de sementes germinadas, número de sementes duras, número de sementes inviáveis e número de plântulas normais. O potencial de armazenamento das sementes de $M$. caesalpiniifolia depende do estádio de maturação dos frutos. Sementes de frutos verdes sem secagem não toleram o armazenamento. Sementes de frutos verdes com secagem a $15 \%$ de teor de água mantêm a viabilidade, por 12 meses, quando armazenadas na temperatura de $10{ }^{\circ} \mathrm{C}$. Sementes de frutos maduros sem secagem mantém a viabilidade por 12 meses, quando armazenadas nas temperaturas de 0 ${ }^{\circ} \mathrm{C}$ e $10^{\circ} \mathrm{C}$.

Palavras-chave adicionais: armazenamento de sementes; Fabaceae; germinação.

\section{Introduction}

The lack of basic knowledge about the production and proper management of native seeds is one of the factors that can interfere in the availability of seeds for the market (Calvi, 2015), which is one of the main obstacles to meet the demands for the commercial production of forest products and for the recovery of ecosystems in Brazil.
Native species are not regular in terms of seed production period. Depending on the species, there may be a year of high production followed by one or two without production (Fowler \& Martins, 2001). Therefore, storage is a necessary practice to ensure the supply of seeds and seedlings and, according to Kissmann et al. (2009), appropriate technology for each species should be employed in order to keep seeds viable and reduce the rate of deterioration during storage. 
In order to define seed storage techniques, it is necessary to know a priori their physiological behavior in relation to storage. In general, seeds are divided into three categories: orthodox, which tolerate drying at water contents between 2 and $5 \%$ and storage at negative temperatures; intermediate, which tolerate drying at water contents between 7 and $11 \%$, but are sensitive to negative temperatures; and recalcitrant, which do not tolerate drying at water content below 20\% and storage at low temperatures (Hong \& Ellis, 1996).

The maintenance of seed viability and vigor during storage is influenced by several factors related to the species and to the environment, including the water content of the seeds, the physiological potential at harvest and the temperature of the environment (Marcos Filho, 2015). Water content and temperature are the most important conditions that affect seed longevity during storage; high temperature and humidity accelerate seed deterioration, while low humidity and temperature reduce (Bewley et al., 2013). The stage of seed maturity at harvest is another aspect that can affect longevity during storage (Bewley et al., 2013; Colville, 2017). Seeds harvested very early or late tend to have low vigor and longevity (Colville, 2017).

Mimosa caesalpiniifolia Benth. (Fabaceae), popularly known in Portuguese as 'sabiá' or 'sansão docampo', is a forest species native to the Northeast region of Brazil (Dutra et al., 2020), with multiple potentials of use, such as, recomposition of degraded areas (Alves et al., 2004), folk medicine (Albuquerque et al., 2007), production of posts, stakes, lampposts, firewood and coal (Pinto et al., 2016; Avelino et al., 2018; Araujo \& Paes, 2018; Araujo et al., 2020; Lins et al., 2020), landscaping and construction of living fences (Araujo \& Paes, 2018).

Given the silvicultural importance of $M$. caesalpiniifolia, the demand for its seeds is expected to increase in the near future (Araujo et al., 2020). Thus, the present study aimed to determine the viability of Mimosa caesalpiniifolia seeds from unripe and ripe fruits stored at different temperatures (ambient, $10 \stackrel{\circ}{\circ}$, $0 \stackrel{\circ}{\circ} \mathrm{C}$ and $-21^{\circ} \mathrm{C}$ ).

\section{Material and methods}

Mimosa caesalpiniifolia fruits were collected from eleven plants located at the Experimental Farm of the Federal University of Recôncavo da Bahia (UFRB), Cruz das Almas campus, at the coordinates $12^{\circ} 39^{\prime} 19^{\prime \prime}$ $S$ and $39^{\circ}$ 04' 57" W, in September 2018. According to the Köppen-Geiger classification (Alvares et al., 2013), the climate of the region is Af type, with an average annual temperature of $24^{\circ} \mathrm{C}$, average annual rainfall of $1224 \mathrm{~mm}$ and relative humidity of $80 \%$.

The fruits were separated based on the external color, green and brown, and characterized with the maturity stages unripe and ripe, respectively (Nogueira et al., 2013). The seeds were extracted from the fruits manually and grouped into two lots: seeds from unripe fruits and seeds from ripe fruits (Figure 1).
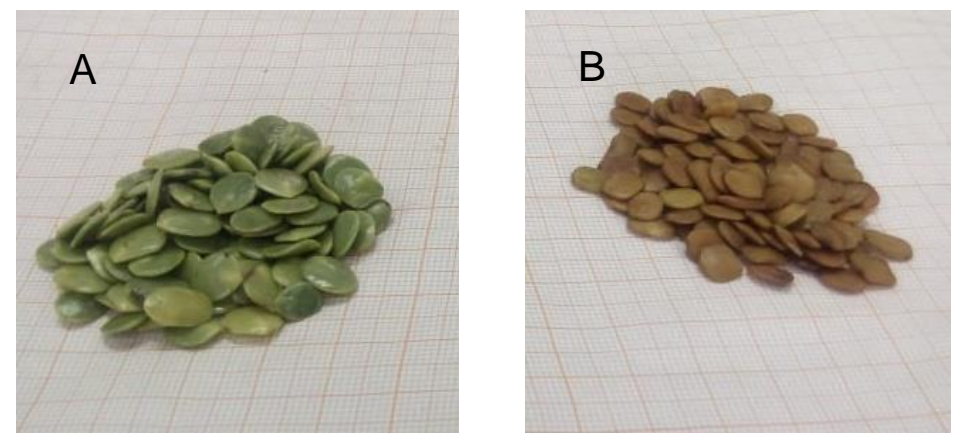

Figure 1 - Mimosa caesalpiniifolia Benth. seeds from unripe fruits $(A)$ and ripe fruits $(B)$.

To evaluate the physiological quality of the seeds prior to storage, a sample of each seed lot was subjected to water content determination and germination test. Another sample of seeds from unripe fruits was dried until it reached $15 \%$ water content (value close to the initial water content of seeds from ripe fruits), by the silica gel method, at $20^{\circ} \mathrm{C}$ (Hong \& Ellis, 1996). Then, a subsample of these seeds was subjected to the germination test.

The seeds without drying and with drying were placed in Falcon tubes and stored at different temperatures, composing 12 treatments: 1 . seeds from ripe fruits without drying, in an environment without temperature control (average of $24^{\circ} \mathrm{C}$ ); 2 . seeds from ripe fruits without drying, in B.O.D. germination chamber at $10{ }^{\circ} \mathrm{C}$; 3 . seeds from ripe fruits without drying, in B.O.D. germination chamber at $0{ }^{\circ} \mathrm{C} ; 4$. Seeds from ripe fruits without drying, in freezer at $-21^{\circ} \mathrm{C} ; 5$. Seeds from unripe fruits without drying, in an environment without temperature control (average of $24^{\circ} \mathrm{C}$ ); 6 . Seeds from unripe fruits without drying, in B.O.D. germination chamber at $10^{\circ} \mathrm{C} ; 7$. Seeds from unripe fruits without drying, in B.O.D. germination chamber at $0^{\circ} \mathrm{C} ; 8$. Seeds from unripe fruits without drying, in freezer at $-21^{\circ} \mathrm{C} ; 9$. Seeds from unripe fruits with drying, in an environment without temperature control (average of $24{ }^{\circ} \mathrm{C}$ ); 10. Seeds from unripe fruits with drying in a B.O.D. germination chamber at $10^{\circ} \mathrm{C} ; 11$. Seeds from unripe fruits with drying, in B.O.D. germination chamber at 0 ${ }^{\circ} \mathrm{C} ; 12$. Seeds from unripe fruits with drying, in freezer at 
$-21^{\circ} \mathrm{C}$. The storage periods evaluated were 3,6 and 12 months.

In each storage period, part of the seeds of each treatment was subjected to water content determination and germination test. The tests to determine the water content of the seeds were performed by the oven method at $105 \pm 3{ }^{\circ} \mathrm{C}$, for 24 hours (Brasil, 2009). Germination tests were conducted on Germitest ${ }^{\circledR}$ paper rolls, moistened with distilled water (2.5 times the mass (g) of the dry paper), packed in transparent polyethylene bags and kept in a B.O.D. germination chamber, with temperature of $30{ }^{\circ} \mathrm{C}$ and photoperiod of 12 hours.

The experimental design was completely randomized, with four replicates of 25 seeds, per treatment. Germination performance was evaluated daily until the stabilization of germination (seven days without occurrence of the event), by counting the number of germinated seeds (2-mm-long radicle), hard seeds and dead seeds, and the numbers of normal and abnormal seedlings (Brasil, 2009). At the end of each germination test, the seeds that remained hard were subjected to the tetrazolium test at $0.5 \%$ for 2 hours at a temperature of $30{ }^{\circ} \mathrm{C}$ (Marcos Filho, 2015), for evaluation of viability.

The variables (random component) number of germinated seeds, number of hard seeds, number of unviable seeds and number of normal seedlings, obtained in the treatments used (systematic component), were analyzed by generalized linear models, with binomial distribution and logit link function, and the inferences of the deviance analysis were based on the chi-square statistics, as recommended by Carvalho et al. (2018). The amplitudes of differences between treatments were verified by Tukey's multiple means comparison test, with confidence interval correction by the Sidák method. These analyses were performed using the packages Emmeans (Lenth et al.,
2020) and MultcompView (Graves et al., 2019) in the R Core Team 3.5.3 program (R Development Core Team, 2019).

\section{Results and discussion}

The average initial water content of the newly harvested seeds of $M$. caesalpiniifolia was $52.76 \%$ for those from unripe fruits, with Confidence Interval-Cl ${ }_{95 \%}$ of $52.76 \% \pm 0.73 \%$, and $16.35 \%$ for those from ripe fruits, with a confidence interval-Cl $195 \%$ of $16.35 \% \pm$ $1.67 \%$. A similar result was obtained by Nogueira et al. (2013), who evaluated M. caesalpiniifolia seeds in five maturity stages and found that, as the seeds matured, there was a reduction in their water content $(45.2 \%$, $36.4 \%, 32.9 \%, 17.1 \%, 11.0 \%$ ). Orthodox seeds, at the maturity stage, lose most of their water, a characteristic that favors their survival after dispersion, until environmental conditions are adequate for germination and plant establishment (Buitink et al., 2006). This characteristic is also important for ex situ conservation, because the low water content restricts deterioration and preserves the physiological potential of seeds for longer periods (Marcos Filho, 2015).

The result of the analysis for seed germination before storage is shown in table 1. The highest percentage of germination was observed in seeds from unripe fruits without drying (84\%) and the highest percentage of normal seedlings in seeds from unripe fruits with drying (70\%). However, there was no significant difference for these variables between seeds from ripe fruits without drying, seeds from unripe fruits without drying and seeds from unripe fruits with drying. These results indicate that seeds from unripe and ripe fruits have the same germination potential and that seeds from unripe fruits have drought tolerance.

Table 1 - Percentage of germinated, unviable and hard seeds and formation of normal seedlings of Mimosa caesalpiniifolia Benth., before storage.

\begin{tabular}{lcccl}
\hline Treatments & $\%$ Germinated & \% Normal seedlings & $\%$ Hard & \% Unviable \\
\hline RWoD & $75.0 \pm 10.3 \mathrm{a}$ & $64.0 \pm 11.5 \mathrm{a}$ & $24.0 \pm 10.2 \mathrm{a}$ & $12.0 \pm 7.8 \mathrm{~b}$ \\
UWoD & $84.0 \pm 8.8 \mathrm{a}$ & $57.0 \pm 11.8 \mathrm{a}$ & $16.0 \pm 8.8 \mathrm{a}$ & $27.0 \pm 10.6 \mathrm{a}$ \\
UWiD & $80.0 \pm 9.6 \mathrm{a}$ & $70.0 \pm 10.9 \mathrm{a}$ & $0.0 \pm 0.0 \mathrm{~b}$ & $30.0 \pm 10.9 \mathrm{a}$ \\
\hline
\end{tabular}

Means followed by the same letter in the column do not differ by Tukey test $(p>0.05)$. Seeds from ripe fruits without drying $(R W o D)$, seeds from unripe fruits without drying (UWoD) and seeds from unripe fruits with drying at $15 \%$ water content (UWiD).

For hard and unviable seeds, differences were detected between treatments (Table 1). The percentage of unviable seeds, consisting of the sum of dead seeds and abnormal seedlings, was higher in those from unripe fruits, indicating that, although these seeds have acquired the ability to germinate, they have probably not yet reached physiological maturity, which corresponds to the stage at which they have the maximum germination potential and vigor (Marcos Filho, 2015). In a study on the maturation of Caesalpinia echinata, Borges et al. (2005) verified that seeds harvested before physiological maturity are capable of germinating, but have low vigor.

The results of water content of the seeds during the storage period are presented in Table 2, which shows that the water content varied little throughout storage in most treatments. 
Table 2 - Confidence intervals $(\alpha=0.05)$ for water content of Mimosa caesalpiniifolia Benth. seeds from ripe fruits without drying (RWoD), green fruit seeds without drying (UWoD) and green fruit seeds with drying at $15 \%$ water content (UWiD), as a function of storage time (ST).

\begin{tabular}{ccccc}
\hline ST (months) & Temperature $\left({ }^{\circ} \mathrm{C}\right)$ & RWoD & UWoD & UWiD \\
\hline 3 & WoC & $12.08 \pm 1.18$ & $60.5 \pm 7.5$ & $15.59 \pm 3.45$ \\
3 & 10 & $12.02 \pm 1.39$ & $58.6 \pm 3.7$ & $13.86 \pm 1.90$ \\
3 & 0 & $11.76 \pm 3.18$ & $51.0 \pm 2.7$ & $14.53 \pm 3.75$ \\
3 & -21 & $12.25 \pm 1.74$ & $50.9 \pm 3.6$ & $13.40 \pm 2.96$ \\
\hline 6 & WoC & $11.59 \pm 1.82$ & $51.4 \pm 7.3$ & $16.47 \pm \pm^{*}$ \\
6 & 10 & $12.50 \pm 1.08$ & $57.5 \pm 15.3$ & $14.31 \pm 1.05$ \\
6 & 0 & $9.74 \pm 2.31$ & $53.7 \pm 3.2$ & $11.11 \pm 1.65$ \\
6 & -21 & $19.62 \pm 5.81$ & $34.1 \pm 10.0$ & $13.70 \pm 5.01$ \\
\hline 12 & WoC & $15.07 \pm 0.16$ & $48.1 \pm 14.0$ & $15.65 \pm 2.03$ \\
12 & 10 & $15.97 \pm 1.99$ & $59.52 \pm 2.3$ & $17.75 \pm 1.13$ \\
12 & 0 & $16.76 \pm^{*}$ & $56.7 \pm 3.1$ & $15.96 \pm 2.26$ \\
12 & -21 & $15.93 \pm 2.01$ & $61.1 \pm 1.9$ & $18.39 \pm 0.62$ \\
\hline
\end{tabular}

*Loss of samples made it impossible to obtain the confidence interval. WoC $=$ without temperature control (laboratory room temperature)

Seeds from unripe fruits without drying did not tolerate storage at any of the temperatures tested. Germination was zero in all periods and the tetrazolium test made it possible to confirm that all seeds were dead. The loss of viability observed may be related to the combination of two factors: high water content of the seeds and storage temperatures. Water and temperature are the main factors that influence seed viability during storage (Bewley et al., 2013; Colville, 2017). Seeds stored with high water content and exposed to higher temperatures exhibit intense respiratory activity, which favors the accumulation of reactive oxygen species (ROS) (Ebone et al., 2019; Zhang et al., 2021). ROS cause oxidative damage to lipids, proteins and nucleic acids and accelerate the process of aging and loss of seed viability (Zhang et al.,
2021). In seeds stored with high water content and exposed to freezing temperatures, the loss of viability may be associated with cellular damage caused by the formation of ice crystals (Hellmann et al., 2006; Marcos Filho, 2015).

At three months, germination and formation of normal seedlings were above $85 \%$, regardless of seed maturity stage and storage temperature, except for green seeds with drying, stored in an environment without temperature control (Table 3). Although the germination performance was lower in this treatment, the percentages obtained for the variables analyzed were close to those of the newly collected seeds. These results show that, at three months of storage, the physiological quality of the seeds was maintained in all treatments.

Table 3 - Percentage of germinated seeds, normal seedlings and unviable seeds of Mimosa caesalpiniifolia Benth., after three months of storage at different temperatures.

\begin{tabular}{ccccccc}
\hline & \multicolumn{2}{c}{ Germinated (\%) } & \multicolumn{2}{c}{ Normal Seedlings (\%) } & \multicolumn{2}{c}{ Unviable (\%) } \\
Temp. $\left({ }^{\circ} \mathrm{C}\right)$ & RWoD & UWiD & RWoD & UWiD & RWoD & UWiD \\
\hline WoC & $96.0 \pm 4.5 \mathrm{Aa}$ & $79.0 \pm 10.1 \mathrm{Bb}$ & $93.0 \pm 6.4 \mathrm{Aa}$ & $78.0 \pm 10.3 \mathrm{Ab}$ & $7.0 \pm 6.4 \mathrm{Ab}$ & $22.0 \pm 10.3 \mathrm{Aa}$ \\
10 & $91.0 \pm 7.1 \mathrm{Aa}$ & $88.0 \pm 8.1 \mathrm{ABa}$ & $89.0 \pm 7.8 \mathrm{Aa}$ & $86.0 \pm 8.6 \mathrm{Aa}$ & $11.0 \pm 7.8 \mathrm{Aa}$ & $14.0 \pm 8.6 \mathrm{Aa}$ \\
0 & $89.0 \pm 7.8 \mathrm{Aa}$ & $94.0 \pm 5.9 \mathrm{Aa}$ & $88.0 \pm 8.1 \mathrm{Aa}$ & $89.0 \pm 7.8 \mathrm{Aa}$ & $12.0 \pm 8.1 \mathrm{Aa}$ & $11.0 \pm 7.8 \mathrm{Aa}$ \\
-21 & $87.0 \pm 8.4 \mathrm{Aa}$ & $83.0 \pm 9.4 \mathrm{ABa}$ & $86.0 \pm 8.6 \mathrm{Aa}$ & $80.0 \pm 10.0 \mathrm{Aa}$ & $14.0 \pm 8.6 \mathrm{Aa}$ & $20.0 \pm 10.0 \mathrm{Aa}$ \\
\hline
\end{tabular}

$\overline{\mathrm{WoC}}=$ without temperature control (laboratory room temperature). Means followed by the same uppercase letter in the column and lowercase letter in the row do not differ by Tukey test $(p>0.05)$. Seeds from ripe fruits without drying (RWoD), seeds from unripe fruits without drying (UWoD) and seeds from unripe fruits with drying at 15\% water content (UWiD).

After storage for six months, the percentages of germination and normal seedlings for seeds from ripe fruits without drying reduced only at $-21^{\circ} \mathrm{C}$ (Table 4$)$. In this treatment, there was a low percentage of unviable seeds, and the reduction in germination performance observed was due to a higher amount of hard seeds. These results were very close to that of the newly collected seeds and, therefore, it can be inferred that there was no loss of viability and/or vigor in this treatment. The obtained percentage of hard seeds may have resulted from the presence of dormancy, since no pre-germinative treatment was used in the present study. Mimosa caesalpiniifolia seeds have dormancy characterized by seed coat impermeability to water, 
which is established at the end of the maturation stage, when the seeds have already lost most of their water content (Nogueira et al., 2013).

Table 4 - Percentages of germinated seeds, normal seedlings, unviable seeds and hard seeds of Mimosa caesalpiniifolia Benth., after six months of storage at different temperatures.

\begin{tabular}{ccc}
\hline Temperature $\left({ }^{\circ} \mathrm{C}\right)$ & Germinated $(\%)$ & UWiD \\
WoC & RWoD & $97.0 \pm 11.7 \mathrm{Cb}$ \\
10 & $92.0 \pm 6.8 \mathrm{Aa}$ & $95.0 \pm 5.4 \mathrm{Aa}$ \\
0 & $95.0 \pm 5.4 \mathrm{Aa}$ & $87.0 \pm 8.4 \mathrm{ABa}$ \\
-21 & $93.0 \pm 6.4 \mathrm{Aa}$ & $81.0 \pm 9.8 \mathrm{BCa}$ \\
\hline & $76.0 \pm 10.6 \mathrm{Ba}$ & UWiD \\
Temperature $\left({ }^{\circ} \mathrm{C}\right)$ & Normal seedlings $(\%)$ & $56.0 \pm 12.4 \mathrm{Bb}$ \\
WoC & $85.0 \pm 8.9 \mathrm{ABa}$ & $90.0 \pm 7.5 \mathrm{Aa}$ \\
10 & $87.0 \pm 8.4 \mathrm{ABa}$ & $73.0 \pm 9.8 \mathrm{Bb}$ \\
0 & $93.0 \pm 6.4 \mathrm{Aa}$ & $69.0 \pm 11.5 \mathrm{Ba}$ \\
-21 & $75.0 \pm 10.8 \mathrm{Ba}$ & UWiD \\
\hline Temperature $\left({ }^{\circ} \mathrm{C}\right)$ & Unviable $(\%)$ & $44.0 \pm 12.4 \mathrm{Aa}$ \\
WoC & $\mathrm{RWoD}$ & $10.0 \pm 7.5 \mathrm{Ca}$ \\
10 & $15.0 \pm 8.9 \mathrm{Ab}$ & $27.0 \pm 11.1 \mathrm{ABa}$ \\
0 & $13.0 \pm 8.4 \mathrm{ABa}$ & $21.0 \pm 10.1 \mathrm{BCa}$ \\
-21 & $4.0 \pm 4.9 \mathrm{Bb}$ & UWiD \\
\hline Temperature $\left({ }^{\circ} \mathrm{C}\right)$ & $4.0 \pm 4.9 \mathrm{Bb}$ & $0.0 \pm 0.0 \mathrm{Ba}$ \\
WoC & Hard $(\%)$ & $0.0 \pm 0.0 \mathrm{Ba}$ \\
10 & $\mathrm{RWoD}$ & $0.0 \pm 0.0 \mathrm{Bb}$ \\
0 & $0.0 \pm 0.0 \mathrm{Ca}$ & $10.0 \pm 8.6 \mathrm{Ab}$ \\
\hline-21 & $0.0 \pm 0.0 \mathrm{Ca}$ & $7.0 \pm 6.4 \mathrm{Ba}$ \\
\hline
\end{tabular}

$\overline{\mathrm{WoC}}=$ without temperature control (laboratory room temperature). Means followed by the same uppercase letter in the column and lowercase letter in the row do not differ by Tukey test $(p>0.05)$. Seeds from ripe fruits without drying $(R W o D)$, seeds from unripe fruits without drying (UWoD) and seeds from unripe fruits with drying at $15 \%$ water content (UWiD).

The seeds from unripe fruits with drying stored in an environment without temperature control showed the lowest percentages of germination and normal seedlings and the highest percentage of unviable seeds (Table 4). Most of the unviable seeds consisted of dead seeds, indicating that storage at room temperature negatively influenced the viability of these seeds. For seeds from unripe fruits with drying stored at $0^{\circ} \mathrm{C}$ and $21^{\circ} \mathrm{C}$, there were also a significant reduction in the percentage of normal seedlings and an increase in the percentage of unviable seeds (Table 4). In these treatments, the number of unviable seeds consisted mainly of abnormal seedlings, suggesting that there was a reduction in vigor.

At 12 months, storage in an environment without temperature control favored the reduction of viability and vigor of seeds from ripe fruits without drying and the loss of viability of seeds from unripe fruits with drying (Table 5). Storage at temperatures of $10^{\circ} \mathrm{C}, 0 \stackrel{\circ}{ } \mathrm{C}$ and $-21^{\circ} \mathrm{C}$ promoted the maintenance of physiological quality for both seeds from ripe fruits without drying and seeds from unripe fruits with drying (Table 5 ).

The observed results indicate that storage for 12 months in an environment without temperature control (mean of $24{ }^{\circ} \mathrm{C}$ ) enhances the process of deterioration of $M$. caesalpiniifolia seeds. Storage at room temperature also promoted faster loss of viability of Caesalpinia echinata seeds, at three months (Hellman et al., 2006), Tabebuia caraiba seeds, at three months (Guedes et al., 2012b), Myracrodruon urundeuva seeds, at 150 days (Guedes et al., 2012a) and Melanoxylon brauna seeds, at 24 months (Freire et al., 2021), compared to colder temperatures. 
Table 5 - Percentages of germinated seeds, normal seedlings, unviable seeds and hard seeds of Mimosa caesalpiniffolia Benth., after twelve months of storage at different temperatures.

\begin{tabular}{|c|c|c|}
\hline \multicolumn{3}{|c|}{ Germinated (\%) } \\
\hline Temperature $\left({ }^{\circ} \mathrm{C}\right)$ & RWoD & UWiD \\
\hline WoC & $76.0 \pm 10.6 \mathrm{Ba}$ & $0.0 \pm 0.0 \mathrm{Bb}$ \\
\hline 10 & $95.0 \pm 9.9 \mathrm{Aa}$ & $92.0 \pm 6.8 \mathrm{Aa}$ \\
\hline 0 & $92.0 \pm 6.8 \mathrm{Aa}$ & $88.0 \pm 8.1 \mathrm{Aa}$ \\
\hline-21 & $89.0 \pm 7.8 \mathrm{ABa}$ & $82.0 \pm 9.6 \mathrm{Aa}$ \\
\hline \multicolumn{3}{|c|}{ Normal seedlings (\%) } \\
\hline Temperature $\left({ }^{\circ} \mathrm{C}\right)$ & RWoD & UWiD \\
\hline WoC & $58.0 \pm 12.3 \mathrm{Ba}$ & $0.0 \pm 10.0 \mathrm{Bb}$ \\
\hline 10 & $88.0 \pm 8.1 \mathrm{Aa}$ & $84.0 \pm 9.1 \mathrm{Aa}$ \\
\hline 0 & $85.0 \pm 8.9 \mathrm{Aa}$ & $72.0 \pm 11.2 \mathrm{Ab}$ \\
\hline-21 & $89.0 \pm 7.8 \mathrm{Aa}$ & $77.0 \pm 6.0 \mathrm{Ab}$ \\
\hline \multicolumn{3}{|c|}{ Unviable (\%) } \\
\hline Temperature $\left({ }^{\circ} \mathrm{C}\right)$ & RWoD & UWiD \\
\hline WoC & $40.0 \pm 12.2 \mathrm{Ab}$ & $100.0 \pm 0.5 \mathrm{Aa}$ \\
\hline 10 & $11.0 \pm 7.8 \mathrm{Ba}$ & $16.0 \pm 9.1 \mathrm{Ba}$ \\
\hline 0 & $12.0 \pm 8.1 \mathrm{Bb}$ & $26.0 \pm 10.9 \mathrm{Ba}$ \\
\hline-21 & $4.0 \pm 4.9 \mathrm{Bb}$ & $21.0 \pm 10.1 \mathrm{Ba}$ \\
\hline \multicolumn{3}{|c|}{ Hard (\%) } \\
\hline Temperature $\left({ }^{\circ} \mathrm{C}\right)$ & RWoD & UWiD \\
\hline WoC & $2.0 \pm 3.5 \mathrm{Aa}$ & $0.0 \pm 0.0 \mathrm{Aa}$ \\
\hline 10 & $1.0 \pm 2.5 \mathrm{Aa}$ & $0.0 \pm 0.0 \mathrm{Aa}$ \\
\hline 0 & $3.0 \pm 4.3 \mathrm{Aa}$ & $2.0 \pm 3.5 \mathrm{Aa}$ \\
\hline-21 & $0.0 \pm 0.0 \mathrm{Aa}$ & $0.0 \pm 0.0 \mathrm{Aa}$ \\
\hline
\end{tabular}

$\overline{\mathrm{WoC}}=$ without temperature control (laboratory room temperature). Means followed by the same uppercase letter in the column and lowercase letter in the row do not differ by Tukey test $(p>0.05)$. Seeds from ripe fruits without drying $(R W o D)$, seeds from unripe fruits without drying (UWoD) and seeds from unripe fruits with drying at $15 \%$ water content (UWiD).

Several factors influence the rate of deterioration of seeds, including their initial physiological quality and storage temperature (Marcos Filho, 2015). Seeds harvested with incomplete maturity and/or lower vigor show greater intensity of deterioration during storage (Marcos Filho, 2015), which may explain the fact that seeds from unripe fruits were more affected. Storage at high temperatures increases metabolic activity, consumption of reserves and oxidative stress in seeds, which intensifies the deterioration process (Ebone et al., 2019; Zhang et al., 2021).

\section{Conclusions}

The degree of fruit maturity interferes with the storage potential of $M$. caesalpiniifolia seeds.

M. caesalpiniifolia seeds from unripe fruits and dried at $15 \%$ of water content can be stored for 12 months at $10^{\circ} \mathrm{C}$, without loss of viability and vigor.

M. caesalpiniifolia seeds from ripe fruits and not subjected to drying maintain viability and vigor for 12 months, when stored at temperatures of $10^{\circ} \mathrm{C}$ and $0^{\circ} \mathrm{C}$.

\section{References}

Albuquerque UP, Medeiros PM, Almeida ALS, Monteiro JM, Lins Neto EMF, Melo JG, Santos JP (2007) Medicinal plants of the caatinga (semi-arid) vegetation of NE Brazil: A quantitative approach. Journal of Ethnopharmacology 114(3):325-354.

Alvares CA, Stape JL, Sentelhas PC, Gonçalvez JLM, Sparovek, G (2013) Köppen's climate classification map for Brazil. Meteorologische Zeitschrift 22(6):711-728.

Alves EU, Saderi R, Bruno RLA, Alves AU (2004) Dormência e desenvolvimento de sementes de sabiá (Mimosa caesalpiniifolia Benth.). Revista Árvore 28(5):655-662.

Araujo FS, Felix FC, Ferrari CS, Vieira FA, Pacheco MV (2020) Seed quality and genetic diversity of a cultivated population of Mimosa caesalpinifolia Benth 33(4):10001006.

Araujo JBS, Paes JB (2018) Natural Wood Resistance of Mimosa caesalpiniifolia in Field Testing. Floresta e Ambiente 25(2):e20150128.

Avelino MCS, Felix FC, Silva KRG, Araújo FS, Pacheco MV (2018) Testes bioquímicos de integridade de 
membranas na avaliação do vigor de sementes de Mimosa caesalpiniifolia Benth. Revista de Ciências Agrárias 41(1):100-108.

Bewley JD, Bradford K, Hilhorst HWM, Nonogaki H (2013) Seeds: Physiology of Development, Germination and Dormancy, 3 ed, Springer. 392p.

Borges IF, Giudice JD, Bilia DAC, Figueiredo-Ribeiro RCL, Barbedo CJ (2005) Maturation of seeds of Caesalpinia echinata Lam. (Brazilwood), an endangered Leguminous tree from the Brazilian Atlantic Forest. Brazilian Archives of Biology and Technology 48(6):851-861.

Brasil (2009) Ministério da Agricultura, Pecuária e Abastecimento. Regras para análise de sementes. Brasília. 399p.

Buitink J, Leger JJ, Guisle I, Vu BL, Wuillème $S$, Lamirault G, Le Bars A, Le Meur N, Becker A, Kuester $\mathrm{H}$, Leprince $\mathrm{O}$ (2006) Transcriptome profiling uncovers metabolic and regulatory processes occurring during the transition from desiccation-sensitive to desiccationtolerant stages in Medicago truncatula seeds. Plant Journal 47:735-750.

Calvi GP (2015) Armazenamento das Sementes Recalcitrantes de Eugenia Stipitata Mcvaugh: Aspectos Tecnológicos e Fisiológicos. Inpa (Tese de Doutorado).

Carvalho FJ, Santana DG, Araújo LB (2018) Why analyze germination experiments using Generalized Linear Models?. Journal of Seed Science 40(3):281287.

Colville L (2017) Seed storage. In: Thomas B, Murray BG, Murphy DJ. Encyclopedia of Applied Plant Science, Academic Press. p. 335-339.

Dutra VF, Morales M, Jordão LSB, Borges LM, Silveira FS, Simon MF, Santos-Silva J, Nascimento JGA, Ribas ODS (2020) Mimosa in Flora do Brasil 2020. Jardim Botânico do Rio de Janeiro. Available at: $<$ http://floradobrasil.jbrj.gov.br/reflora/floradobrasil/FB1 8776>. Access on: Mar. 21, 2021

Ebone LA, Caverzan A, Chavarria G (2019) Physiologic alterations in orthodox seeds due to deterioration processes. Plant Physiology and Biochemistry 145:3442.

Fowler JAP, Martins EG (2001) Coleta de sementes. Manejo de sementes de espécies florestais. Colombo: Embrapa Florestas, 76p.

Freire JM, Rouws JRC, Breier TB, Ataíde GM (2021) Drying and storage of Melanoxylon brauna Schott. Seeds. Brazilian Journal of Biology 81(2):464-473.

Graves S, Piepho H-P, Selzer L, Dorai-Raj S (2019) Package 'multcompView'. Available at: https://cran.rpro-

ject.org/web/packages/multcompView/multcompView. pdf. Access on: Mar. 28, 2020.
Guedes RS, Alves EU, Bruno RLA, Gonçalves EP, Costa EG, Medeiros MS (2012a) Armazenamento de sementes de Myracrodruon urundeuva Fr. All. em diferentes embalagens e ambientes. Revista Brasileira de Plantas Medicinais 14(1):68-75.

Guedes RS, Alves EU, Melo PAFR, Moura SSS, Silva RS (2012b) Storage of Tabebuia caraiba (Mart.) Bureau seeds in different packaging and temperatures. Revista Brasileira de Sementes 34(3):433-440.

Hellmann ME, Mello JIO, Figueiredo-Ribeiro RCL, Barbedo CJ (2006) Tolerância ao congelamento de sementes de pau-brasil (Caesalpinia echinata Lam) influenciada pelo teor de água inicial. Revista Brasileira de Botânica 29(1):93-101.

Hong TD, Ellis RH (1996) A protocol to determine seed storage behaviour. International Plant Genetic Resources Institute, 55p.

Kissmann C, Scalon SPQ, Mussury RM, Robaina AD (2009) Germinação e armazenamento de sementes de Albizia hasslerii (Chod.) Burkart. Revista Brasileira de Sementes 31(2):104-115.

Lenth R, Singmann, Love J, Buerkner $P$, Herve $M$ (2020) Package 'emmeans'. Available at: https://cran.rproject.org/web/packages/emmeans/emm eans.pdf. Access on: Mar. 28, 2020.

Lins TRS, Braz RL, Souza Junior CGC, Correia HTV, Silva TC, Walter LS (2020) Rendimento e caracterização do carvão vegetal de galhos de Mimosa caesalpiniifolia Benth. Biofix Scientific Journal 5(1):3943.

Marcos Filho $J$ (2015) Fisiologia de sementes de plantas cultivadas, $2 \mathrm{ed}$, Abrates. 659p.

Nogueira NW, Ribeiro MCC, Freitas RMO, Martins HVG, Leal, CCP (2013) Maturação fisiológica e dormência em sementes de sabiá (Mimosa caesalpiniifolia Benth.). Bioscience Journal 29(4):876883.

Pinto JRS, Dombroski JLD. Santos Junior JH, Souza GO, Freitas RMO (2016) Growth of Mimosa caesalpiniifolia Benth., under shade in the Northeast semi-arid region of Brazil. Revista Caatinga 29(2):384392.

R Development Core Team (2019) R: A language and environment for statistical computing. $R$ Foundation for Statistical Computing, Vienna, Austria. URL https://www.R-project.org/.

Zhang K, Zhang Y, Sun J, Meng J, Tao J (2021) Deterioration of orthodox seeds during ageing: Influencing factors, physiological alterations and the role of reactive oxygen species. Plant Physiology and Biochemistry158:475-485. 